\title{
Investigating Indonesian Spelling Error on the Learners' Composition
}

\section{Dwi Dian Panike}

IAIN Bengkulu

dwidianpanike881@gmail.com

\author{
Kasmantoni \\ IAIN Bengkulu \\ kasmantoni100@gmail.com \\ Randi \\ IAIN Bengkulu \\ jufrirandy@gmail.com
}

\begin{abstract}
The aim of this research was to investigate errors in the implementation of EBI (Indonesian Spelling System) on the learners' composition of the second grade students of SMAN 05 Kepahiang. In order to analyze the case deeply and comprehensively, this research was designed by using qualitative approach and content analysis method with data gathering techniques in the form of documentation. The data of this research were collected through purposive sampling and analyzed by using an interactive model consisting of four stages: data collection, data reduction, data presentation, and withdrawal conclusion. The result of this research revealed that the learners' errors in the implementation of EBI on their composition included misusing of capital letters, italics, prepositions, commas, and compound words. In academic writing, the errors need to be avoided as such errors can interfere with the effectiveness and efficiency of the learners' composition in Indonesian.
\end{abstract}

Keywords: Indonesian Spelling Errors; Composition; Learners

\section{A. Introduction}

According to Kamus Besar Bahasa Indonesia (KBBI), spelling can be defined as the systems and rules of how sounds (words, sentences, punctuation marks, and so forth) are described and used in writing (letters). It means that spelling only relates to writing including the use of letters, loan words, and punctuation marks. Thus, it does not relate to diction and sentence arrangement systems.

Moreover, spelling can be expressed as a crucial set of rules or systems in written communication since it can enable writers to produce an effective composition. It is intended to make the readers get the meaning of the writing easily, and to help the writers express their ideas clearly and accurately. 
Therefore, the use of appropriate spelling has become one of pivotal aspects in writing a paragraph since it can avoid writers making errors which can lead the readers to misunderstanding and misinterpretation (Feny Oktaviani, 2018).

Language error is a part of the language learning process which absolutely cannot be separated by the learners themselves. It is commonly caused by the lack of learners' competence in linguistics comprehension. In this case, it is very necessary to overcome the error on the learners' composition by analyzing it exhaustively. The analysis of Indonesian spelling error has been functioned as the alternative for the teachers and researchers to identify the error consisting of several steps. The steps are data collection, error identification, error explanation, error identification based on the cause, and evaluation

SMAN 05 Kepahiang located in Bermani Ilir Subdistrict has two departments, i.e Ilmu Pengetahuan Alam (IPA) dan Ilmu Pengetahuan Sosial (IPS). In this case, there are four classes of each grade. Moreover, in this research the researchers only focused on the composition written by the second grade students. Based on the preliminary observation at the school, the researchers found that the learners still had poor understanding about Indonesian spelling in composition. It was caused by the material which was not delivered to the learners completely and exhaustively, so the learners were still not able to understand the material comprehensively. In addition, this case was also caused by the use of social media. In this case, the learners used to deal in the social community whose the majority of the people communicated in daily communication (informal communication). It can be reasonable as language rules and the use of effective sentences were not really noticed and implemented in such situations. Thus, the condition became the cause of the error as the learners tend to follow and be more familiar with the incorrect spelling. For instance, when they preferred to write a sentence in uppercase letters and toggle case, or when they misused conjunction in the sentence.

In the context of the aforementioned cases, the researchers were interested in conducting the research entitled "Investigating Indonesian Spelling Error on the Learners' Composition at the Second Grade Students of SMAN 05 
Kepahiang" because the learners had still not understood the Indonesian spelling in the composition.

\section{B. Research Method}

This research was designed by implementing a qualitative approach with a content analysis method. Qualitative research is one of the research approaches used to investigate a certain social situation through description and explanation accurately, faithfully, and deeply formed by words. It is conducted based on the relevant data collection technique and the data analysis technique gained by natural setting (Djam'an Satori and Aan Komariah, 2017). This research took one month (started from February until March 2021). The location of this research was at SMAN 05 Kepahiang located on Desa Talang Pito Street, Bermani Ilir Subdistrict, Kepahiang Regency, Bengkulu Province. Data collection technique of this research was an interactive model.

\section{Result and Discussion}

\section{Result}

Based on the data gained from the learners' spelling errors on their composition at the second grade students of SMAN 05 Kepahiang, the results showed that there were still many spelling errors conducted by the learners. In this case, the researchers decide to explain and describe some types of the errors. The types of spelling errors on the learners' composition at the second grade students of SMAN 05 Kepahiang are explained in the following description:

\section{a. Misusing Letter}

Spelling can be defined as a set of rules used as the guidance of representing utterance sounds, placing capital or non-capital letter, punctuation marks, omitting syllables, and combining words. The presented result of this research included the misuse of Indonesian spelling on the learners' composition at the second grade students of SMAN 05 Kepahiang.

Seen from several errors found on the learners' composition, the researchers limited the gained data based on the research problems stated before i.e Misusing capital and italic letters. 


\section{Misusing Capital Letter}

Capital letter can be used as the first letter of a word to start a sentence, the first letter of direct quotation, the first letter of name of God, the first letter of holy book, the first letter of honorary or descendant title, the first letter of the element of the name of the position, and the first letter of the name of the nation and language.

Based on the analysis of the result, spelling errors in using capital letter on the learners' composition at the second grade students of SMAN 05 Kepahiang were the capital letters that should be placed in the first letter of the word to start the sentence. This error needs to be taken into account so that the learners do not make the same errors in the future. In this case, the researchers found many errors in capital letters.

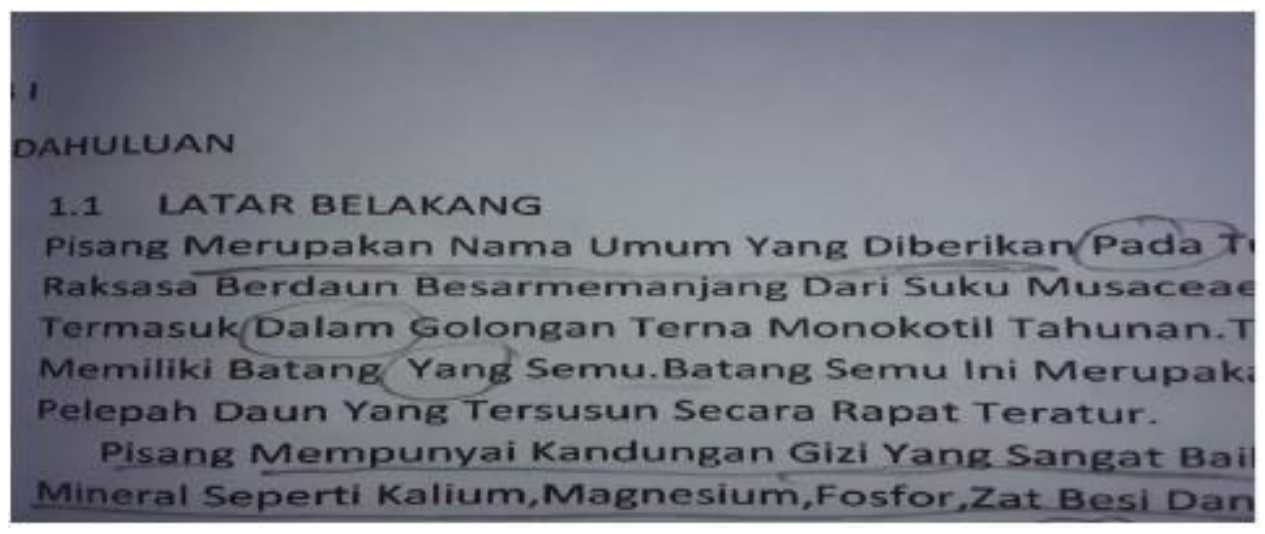

Datum 4.1

Seen from the datum above, it can be seen that there were many Indonesian spelling errors. In this case, the learner used the capital letters in the middle of the sentence. It was counted as the spelling error because the capital letter is only used in the first letter of a word to start a sentence. Thus, when the learner misused the capital letter in the sentence, it clearly showed that the learner had made an Indonesian spelling error on the composition. It can bee seen from the sentence "Merupakan Nama Umum Yang Diberikan Pada Tumbuhan Terna 
Raksasa Berdaun Besar Memanjang Dari Suku Musaceae" which should be written "merupakan nama umum yang diberikan pada tumbuhan terna raksasa berdaun besar memanjang dari suku musaceae" as every first letter of the words in the sentence should be in the non-capital letter. It can be understandable since the words were not used to start the sentence.

\section{Misusing Italics}

The use of italics has three functions. It can be used when a writer wants to write the name of a book, magazine, newspaper cited in the writing, when the writer wants to highlight and specialize a certain letter, word, or compound word.

Based on the result of the data analysis, the researchers found that there were spelling errors in the form of the misuse of italic words on the learners' composition at the second students of IPA class of SMAN 05 Kepahiang. In this case, there were groups of words that should be written in italics that were not used properly. This happened due to the lack of understanding about proper italics. One example of errors made by the learner in writing italics related to writing italics in foreign languages.

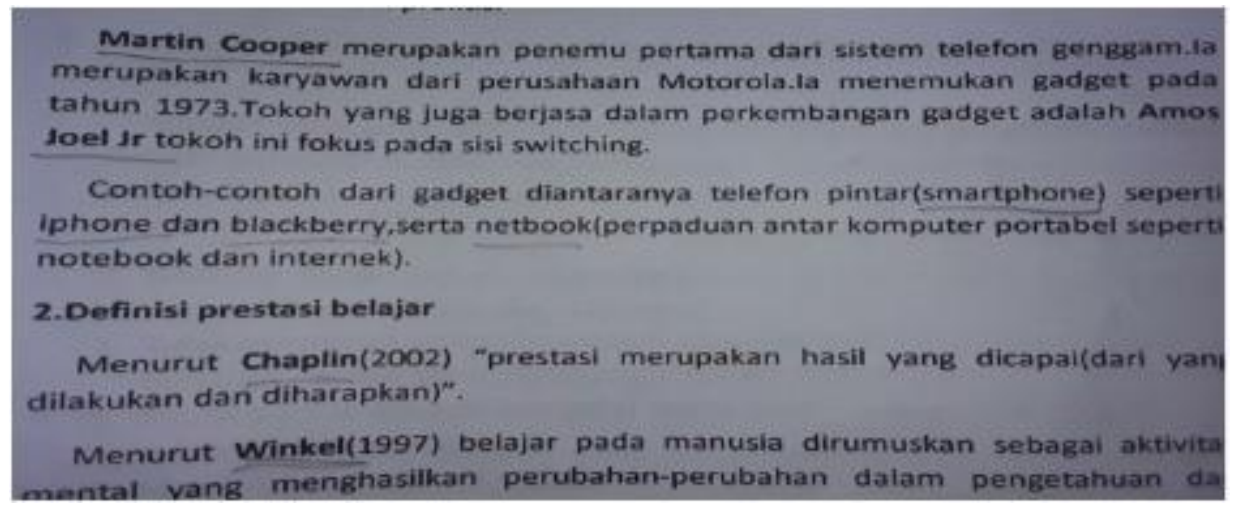

\section{Datum 4.2}

From the datum 4.2, it can be seen that there was the form of Indonesian spelling errors. It happened as the learner did not use italics in writing the foreign words. It was counted as the spelling error as italics cannot be used haphazardly. Based on the EBI, italics can be used in writing book titles, specifying letters, and foreign expressions. 
The datum revealed that the learner did not use italics in writing the foreign words. It was counted as the Indonesian spelling error because foreign language should be in italic in Indonesian language. Therefore, the foreign words "gadget, smartphone, iphone, and blackberry and netbook" should be written "gadget, smartphone, iphone, and blackberry and netbook" in the sentence.

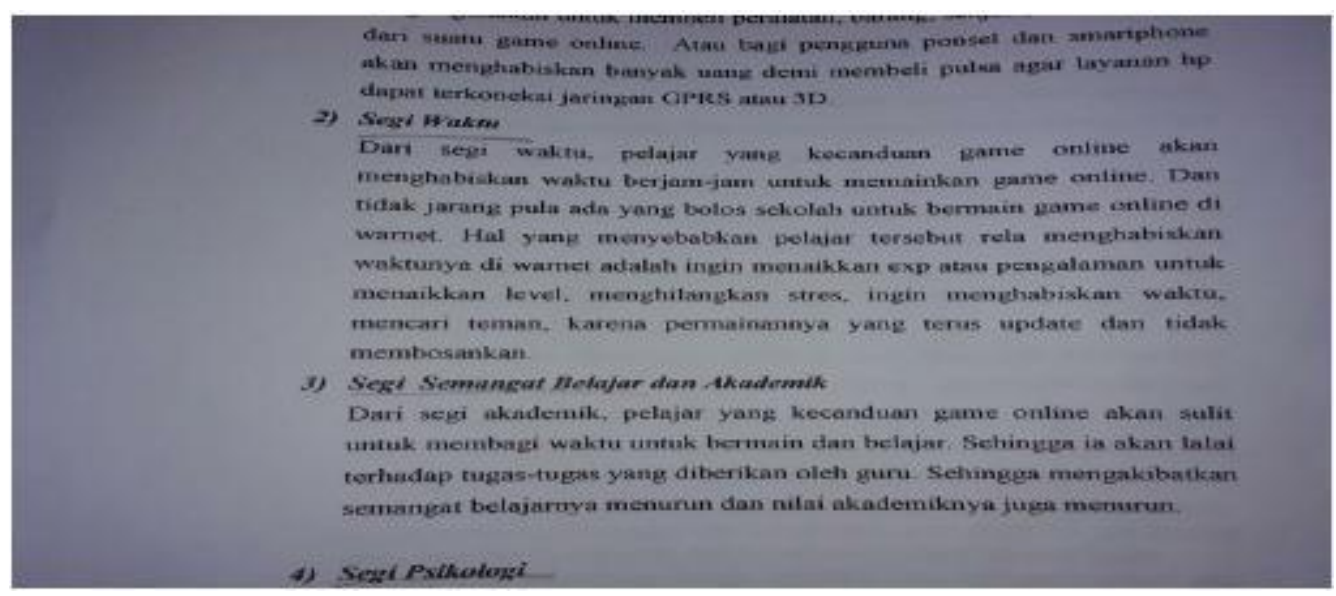

Datum 4.3

In the datum 4.3, it could be seen that there were Indonesian spelling errors on the composition. It showed that the learner used italics in the subtitles which should not be in italics. Thus, it was counted as the spelling error as it was written contrary to the rules of the correct spelling according to PUEBI.

It can be seen from the expressions in the subtitles "segi keuangan", "segi waktu", "segi semangat belajar dan akademik" which were considered as Indonesian expressions. It was considered as the spelling error as the words should not be written in italics whereas in PUEBI it has been explained that the use of italics can be used for foreign expressions, while in Indonesian expressions it is not necessary to be italicized. Thus, the subtitles should be written "segi keuangan", "segi waktu", "segi semangat belajar dan akademik" on the composition. It can be seen clearly that the learner did not follow the rules of the correct spelling in accordance with PUEBI. Therefore, it was counted as a form of language error.

\section{b. Misusing Word}

Word can be deemed as a language unit that contains meaning and consists of one or more morphemes. It commonly contains root words with or without several 
affixes. In other words, words as the basis of the word or on the basis of the experience of repeating the form of all or part of a compound can be the combination of several different basic words to create a new meaning.

Moreover, writing errors can be considered as something normal in writing. It can be understandable as the errors on the level of punctuation, typo or hyphenation become one of common problems faced by novice writers. Nevertheless, such errors will have a negative impact on the learners' composition, if they are made repeatedly. In other words, it can be boomerang on the learners. In this research, the researchers only focused on the errors in misusing prepositions.

\section{Misusing of Preposition}

Tumbuhan Pisang Menyukai Daerah Alam Terbuka Yang Cukup

Sinar Matahari.Pada Dasarnya Tanaman Pisang Meruakan Tumbuhan

Yg Tidak Memillki Batang Sejati.Batang Pisang Sebenarnva Terdapat

Pada Bonggol Yane Tersembunyi Didalam Tanah. Bagian Bawah Batang

Pisang Mengembung Berupa Ubi Yang Disebut Bonggol, Pucuk

Lateral(Sucker)Muncul Dari Kuncup Pada Bonzeol Yang Selanjutnya

Tumbuh Menjadi Tanaman Pisang, Buah Pisang Umumnya Tidak

Berbij/Bersifat Partenokarpi.

\section{Datum 4.4}

In the datum 4.4 the researchers found a form of preposition writing error. Prepositions such as $d i, k e$, and dari were written separately from the words that followed them. It can be seen from the sentence "Batang Pisang Sebenarnya Terdapat Pada Bonggol Yang Tersembunyi Didalam Tanah." The learner misused the preposition of place which should be written "di dalam" in the sentence. Thus, the learner should be able to form the appropriate affixed word appropriately so that the error could be avoided.

\section{c. Misusing Punctuation}

Punctuation is one of the crucial elements used in a sentence. It has the function of providing the right intonation or expression which can lead readers to misunderstandings. Readers or interlocutors can not understand writer' intentions even more fatally if the reader misinterprets the meaning of a sentence into another meaning that is contradictory. Thus, it is a very familiar thing to students.

The use of punctuation absolutely has an important role in producing an effective composition. The use and determination of punctuation properly and 
appropriately indicate good language mastery. It can refer to signs used in the spelling system such as a full stop, comma, colon, and interjection. It can help readers to understand the meaning of writing correctly.

Furthermore, after analysing the learners' compositions at the second grade students of IPA class of SMA Negeri 05 Kepahiang, the researchers still found some errors that occurred in the use of punctuation marks. The errors found on the learners' composition were periods and commas.

\section{Misusing Comma (,)}

Isi Yang Terkandung Dalam Karya limiah Ini Bukan Semata-Mata Pemikiran Dari Penulis, Melainkan Penulis Mengambil Dari Berbagai Macam Referensi Lalu Penulis Rangkum Untuk Menyelesaikan Tugas Ini Dalam Penulisan Karya IImiah Ini Penulis Menyadari Masih Sangat Banyak Kekurangannya Baik Dari Segi Penulisan, Bahasa.Maka Dari itu Penulis Sangat Mengharapkan Kritik Dan Saran Dari Pembaca Untuk Mendorong Penulis Dalam Pembuatan Tugas Selanjutnya Menjadi Lebih Baik Lagi.

\section{Datum 4.5}

In the datum 4.5 the comma (,) was used between the elements in a breakdown or numeration, to separate the equivalent sentence from one sentence to the next equivalent preceded by words seperti and melainkan, to separate the subordinate clause from the main clause and so forth. It seems like there was no use of commas after words or connecting expressions between sentences at the beginning of the sentences. However, the rules of the use of commas in comma expressions emphasizes the connectors of the sentence.

Moreover, it could be seen that after the use of the word the learner did not put a comma, it can be seen from the sentence "maka dari itu, penulis sangat mengharapkan kritik dan saran dari pembaca untuk mendorong penulis dalam pembuatan tugas selanjutnya menjadi baik lagi." The sentence revealed that the learner did not put a comma on the sentence, so that it was considered as the Indonesian spelling error. Thus, the sentence should be written "maka dari itu, penulis sangat mengharapkan kritik dan saran dari pembaca untuk mendorong penulis dalam pembuatan tugas selanjutnya menjadi baik lagi." Moreover, it also could be seen from the previous sentence "dari segi penulisan, bahasa." In this 
case, the sentence should not use a comma in the situation as it needed the connector dan to separate both of the words. Therefore, it should be written "penulisan dan bahasa."

\section{d. Misusing Compound Words}

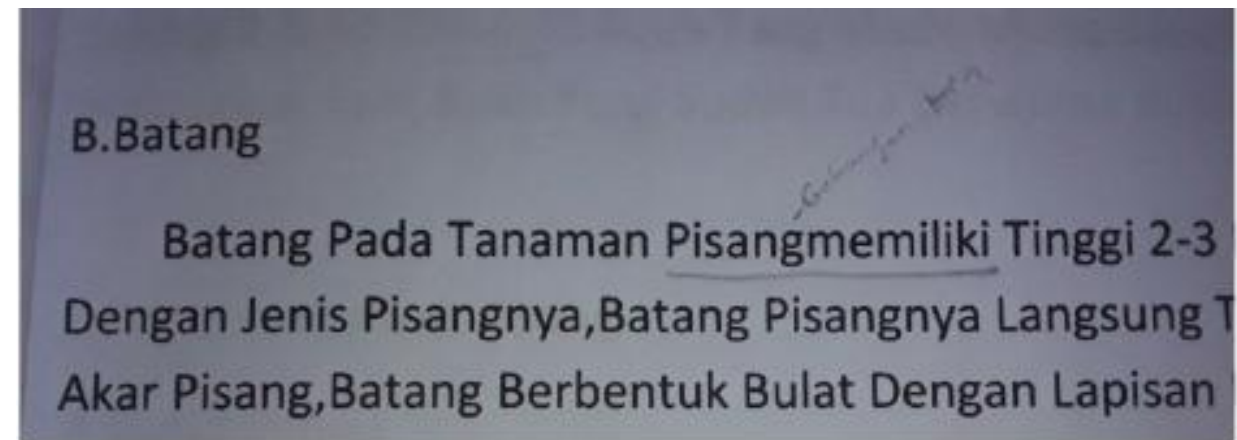

Datum 4.6

In the datum 4.6, it could be seen that the sentence "Pisangmemiliki" in the sentence should be separated because the word "Pisangmemiliki" consisted of the subject and the verb. Thus, in this case the word should be written "Pisang Memiliki" in the sentence separately.

\section{Discussion}

Based on the results of the research through the documentation of student assignments in the form of composition. Seen from the theory that has been explained in the previous chapter which is about how to write in accordance with PUEBI. (Tika Kumala, 2018) Regarding errors in the use of EBI, it is proven that there were many errors that occurred on the learners' composition. Moreover, the findings of this research revealed that the learners still had the lack of knowledge towards the implementation of the appropriate and effective language spelling systems and rules in the composition. In this case, the learners used to make errors in using capital letters, writing italics, determining punctuation, determining prepositions and combining words. Also, the learners were still not able to understand the material pertaining to the composition comprehensively.

In addition, language errors can be referred to as a form of violation of the language code which is not only physical, but also an incomplete knowledge and mastery of the language code. Thus, it can be concluded that language errors are a form of language code violation that occurs in the process of learning languages, 
both first language (L1) and second language (L2), which are caused by the lack of knowledge and mastery of language usage (Kartika Dewi Lutfianti, 2020).

Moreover, spelling refers to a set of the rules of how to describe the sounds of words, sentences, and so forth in written communication (letters) and the use of punctuation marks. Both of these opinions can be concluded that spelling is a written rule in describing a language that is related to the use of letter, word, loanword, and punctuation (Muammar Reza Qhadapi, 2018).

\section{CONCLUSION AND SUGGESTION}

\section{Conclusion}

Based on the results of the research above, it can be concluded that the errors occurred on the learners' composition at the second grade student of SMAN 05 Kepahiang consisted of 5 types of errors including: writing capital letters which should only be used for words at the beginning of sentences, but there were still many errors in using capital letter on the learners' composition. For instance, when the learner used capital letters in the middle of the sentences, misused italicized words which should be used only for foreign sentences and scientific names or those that should be italicized in accordance with the PUEBI. Nevertheless, on the learners' composition, there are many errors in writing italics. For instance, when the learner did not set the foreign sentence in italics, and when they set some expressions that should not be in italics.

Errors in writing prepositions such as the word "didalam" which should be separated because the word cannot be converted into an active sentence, writing a comma used to separate one equivalent sentence from the next equivalent sentence, but on the learners' composition, the learners did not put a comma on elements that should be marked with a comma to separate between one sentence and the other sentence, and errors in determining the combination of words where the learners combined words that did not have a compounding element such as in the word "pisangmemiliki" which should be separated because it consisted of the subject and the predicate. Thus, it should be written separately. Moreover, the researchers found approximately $70 \%$ of errors that occurred on the learners' 
composition at the second grade student of SMAN 05 Kepahiang. Based on the result of the research, the most dominant error was in the use of capital letters

\section{Suggestion}

Based on the results of the research, the researchers conveys several suggestions, namely:

a. The importance of getting used to using good and correct Indonesian for students so that the learners can easily apply Indonesian language rules according to EBI, especially in writing activities.

b. The implementation of learning models, learning media, and examples of the use of Indonesian in accordance with the rules in the school environment to minimize the emergence of spelling errors made by the learners.

c.

\section{References}

Ariningsih, Nur Endah, et.al. (2012). Analisis Kesalahan Berbahasa Indonesia Dalam Karangan Eksposisi Siswa Sekolah Menengah Atas, Skripsi, (Universitas Sebelas Maret, https://jurnal.fkip.uns.ac.id). Retrieved on October 2020.

Ayudia, A., Suryanto, E., \& Waluyo, B. (2017). Analisis kesalahan penggunaan bahasa indonesia dalam laporan hasil observasi pada siswa smp. BASASTRA,4(1).(https://jurnal.fkip.uns.ac.id/index.php/bhs_indonesia/article/ view/9972. Retrieved in February 2021 ).

Badan pengembangan dan pembinaan bahasa kementerian pendidikan dan kebudayaan. 2016. Pedomanumum ejaan bahasa Indonesia (edisi ke empat). Jalan daksinapati barat IV rawamangun, jakarta 13220. Badan pengembangan dan pembinaan bahasa.

Dewi, A. P. (2021). Analisis Kesalahan Berbahasa Indonesia dalam Karya Tulis Ilmiah Sekolah Menengah Kejuruan (SMK) Negeri 2 Surakarta.(https://digilib.uns.ac.id/dokumen/detail/82485/. Retrieved in January 2021).

Fajar, N.U.A. Analisis kesalahan penggunaan ejaan dalam karangan narasi siswa kelas x sma swasta taman siswa binjai tahun pembelajaran 2016/2017. Thesis Journal Bahasa dan Sastra. (https://jurnal.unimed.ac.id, retrieved on 11 November 2020).

Ghufron, S, dkk. 2020. Kesalahan ejaan dan kesalahan penulisan kalimat dalam surat izin siswa. Thesis, (Universitas Nahdlatul Ulama Surabaya). (https://ejournal.bsi.ac.id, retrieved on January 2021).

Humaira, H.H., \& Faizal Arvianto. (2020). Bahasa Indonesia untuk Umum. (https://osf.io/preprints/inarxiv/zw7ne/download. Retrieved on October 2020). 
Jumal, A. (2018). Desain penelitian analisis isi (content analysis). Research gate 5.9. (https://www.researchgate.net/profile/jumalahmad. Retrieved on January 2021 at 14:11 WIB.

Kumala, T ikah. (2018). Pedoman Umum Ejaan Bahasa Indonesia(PUEBI). Perpustakaan Nasional RI : Katalog Dalam Terbitan (KTD).C-klik Media.

Lutfianti Kartika Dewi dkk. (2019). Analisis kesalahan penggunaan ejaan bahasa indonesia pada teks eksposisi karya siswa kelas VIII SMP. (https://unnes.ac.id. Retrieved on 10 November 2020).

Oktaviani, F.R. (2020). Analisis Kesalahan Berbahasa Indonesia Pada Karangan Eksposisi Siswa Kelas x Mipa (studi kasus di sma negeri 4 surakarta). Basastra Jurnal Sastra, Bahasa, dan Pengajarannya. 6(1), 1

Qhadafi, M.R. (2018). Analisis Kesalahan Penulisan Ejaan yang Disempurnakan dalam Teks Negosiasi Siswa SMA Negeri 3 Palu”. Jurnal Bahasa dan Sastra. 3(4), 2.

Rosdiana, L.A. (2020). Kesalahan Ejaan Bahasa Indonesia (EBI) Pada Karya Ilmiah mahasiswa".Jurnal Pendidikan Bahasa dan Sastra Indonesia. vol. 5 no. (https://bahteraindonesia.unwir.ac.id/index.php/bl/article /view/58).

Satori, Djam'an, Komariah, A. (2017). Metodologi Penelitian Kualitatif. Bandung: Alfabeta

Sugiyono. (2017). Metodologi Penelitian Kuantitatif, Kualitatif, dan R\&D. Bandung: Alfabeta. 